\title{
Comparative Study on Application of Bimetallic Pt-Based Alloy Electrocatalysts in Advanced Chlor-Alkali Electrolysis
}

\author{
Faezeh Farzami $^{{ }^{*}}$, Ezzatoalah Joudaki ${ }^{1}$, Seyed Jaleldin Hashemi ${ }^{2}$ \\ ${ }^{1}$ Department of Chemical Engineering, University of Arak, Arak, Iran \\ ${ }^{2}$ Petroleum University of Technology, Ahvaz, Iran \\ E-mail: Faezeh_farzami@yahoo.com
}

Received January 29, 2011; revised May 25, 2011; accepted June 10, 2011

\begin{abstract}
Application of an oxygen-depolarized cathode will contribute to energy saving in chlor-alkali electrolysis. For this purpose, the development of high-performance cathode with the best electrocatalyst is essential. Using bimetallic Pt-based alloy electrocatalysts including PtPd and PtAg carbon-supported in oxygen-depolarized cathode chlor-alkali cell has been shown to have the high cell performance. This study presents application of PtRu carbon supported electrocatalyst oxygen-depolarized cathode and performance comparison of cells with carbon-supported PtRu, PtPd and PtAg electrocatalysts cathodes using the same DSA-Cl $\mathrm{C}_{2}$ anode. Results show that there are quite similarity between the effects of various factors on the caustic current efficiency (CCE) in a zero-gap oxygen-depolarized chlor-alkali cells employing carbon-supported PtPd, PtRu and PtAg electrocatalysts. Besides, it seems that the $\mathrm{PtPd} / \mathrm{C}$ electrocatalyst cathode has relatively higher performance than the other cathodes with $\mathrm{PtAg} / \mathrm{C}$ and $\mathrm{PtRu} / \mathrm{C}$ electrocatalysts in zero-gap chlor-alkali cells.
\end{abstract}

Keywords: Oxygen-Depolarized, Chlor-Alkali, CCE, Electrocatalyst, Performance, Saving Energy

\section{Introduction}

Chlorine as one of the most important bulk chemicals in the world is produced by the brine electrolysis. Chlorine is not only used in the day-to-day life but also is an essential part of the chemical building block that results a myriad of reactions and products in the major plastic, pharmaceutical, inorganic, fine chemical and specialty industries. The chlorine production can therefore be regarded as an indicator of the country's chemical industry state of development. It is an energy intensive process, where consumes electrical power between 2100 and $3300 \mathrm{kWh} \cdot \mathrm{t}^{-1} \mathrm{Cl}_{2}$ depending on the operating parameters and the type of the process. There are three major processes based on mercury, diaphragm and membrane cells for the electrolysis. The membrane cell is the most recent advanced technology with less environmental contamination and electrical power consumption. Despite the fact that the overall energy intensity has been reduced due to the successive introduction of ion exchange membrane cells instead of the "unclean" mercury and diaphragm process, the issue of energy consumption is still a main issue.

Replacing the conventional hydrogen-evolving cathode by oxygen-depolarized cathode in CA membrane cell reduced the cell voltage [1-5] and consequently $30 \%$ energy consumption reduction at $4 \mathrm{kA} \cdot \mathrm{m}^{-2}[4-5]$ and $\mathrm{CO}_{2}$ emission reduction i.e. global environment improvement. The conventional and advanced chlor-alkali cells carbon dioxide emissions are compared for a range of primary energy sources that could be used to generate power [6] (Figure 1). Another difference is the hydrogen generation (a low value byproduct) in chlor-alkali cells with conventional hydrogen-evolving cathodes compared to the oxygen-depolarized cathodes. The utilization of waste hydrogen in conventional chlor-alkali plants with fuel cells has recently become quite popular. The fuel cells can return only around $50 \%$ of the clean hydrogen energy, whereas most of the "dirty" fossil fuel energy is consumed to generate the hydrogen. Also, installation of the fuel cell stacks translates into yet another capital investment. Therefore utilizing the hydrogen "burning" fuel cells in the existing conventional chlor-alkali plants will never compete the oxygen-depolarized cells tech- 
nology. The current chlorine/caustic manufacturing methods will eventually be replaced by the advanced chloralkali technology.

The key element of the advanced chlor-alkali cell is the oxygen-depolarized cathode. An oxygen-depolarized cathode should be designed to facilitate an intimate interaction between oxygen, catholyte and electrocatalyst particles at the three phase boundaries (gas/liquid/solid), in order to reduce oxygen effectively. Due to harsh condition in saturated oxygen and concentrated caustic ofchlor-alkali membrane cell media, the oxygen-depolarized cathodes are more susceptible to performance loss than the conventional hydrogen-evolving cathodes. Another drawback of oxygen-depolarized cathodes in chloralkali cells is the peroxide stability. However the peroxide eventually decomposes to the hydroxide and has no role on energy loss, but the peroxide adverse potential effects on cathode stability [7] and caustic handling issues make it a troublesome byproduct. Different materials with different structures (carbon-based or carbon free electrodes) may be used to construct oxygen-depolarized cathodes. The impact of electrocatalysts to bring about high activity (i.e. high current densities) at lower cell voltages and stable oxygen-depolarized cathode performance over the period of time is of utmost importance. The frequently used catalysts in oxygen-depolarized cathodes are platinum [2-5,7-9] and silver [1,8-9] either carbon supported or as pure metal. Due to high cost of platinum, different techniques such as pt-based alloy electrocatalysts have been developed to reduce loading Pt. The alloyed electrocatalysts composed of two different metal elements have drawn a greater interest than monometallic ones. The reason may be possible catalytic activity improvement. The employment of Pt-based alloy electrocatalysts including PtPd and PtAg carbon-supported in oxygen-depolarized chlor-alkali cathodes has been already reported [10,11]. In this study, the oxygendepolarized cathode implementation containing a carbon supported PtRu electrocatalysts is reported. Its cathode performance that is caustic current efficiency is compared with PtPd and PtAg carbon supported oxygendepolarized cathode performance. The preparations of Pt-alloy electrocatalyst cathodes and their characterizations are also described in brief.

\section{Experimental Preparation and Set up}

\subsection{The Cathode Preparation}

The employed cathodes have the same structure but different Pt-alloy electrocatalysts as reaction layers. The cathodes structure consists of a gas diffusion layer, a reaction layer and a current collector as shown in Figure 2. The gas diffusion layer is a very thin conductive po-

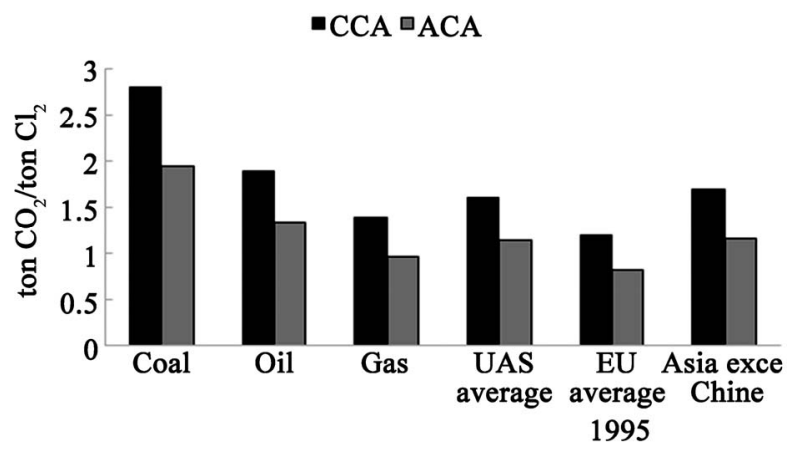

Figure 1. The conventional and the advanced chlor-alkali (CCA \& ACA) cell $\mathrm{CO}_{2}$ emissions from the electrolysis power consumption.

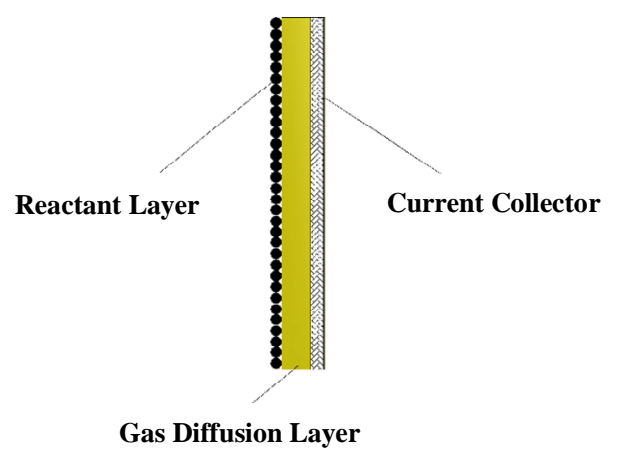

Figure 2. Schematic diagram of the oxygen-depolarized cathode structure.

rous sheet comprising $65 \%-70 \%$ carbon $\left(721 \mathrm{~m}^{2} \cdot \mathrm{gr}^{-1}\right.$ surface area supplied by Iranian Co.) and 35\% - 30\% PTFE powder (Aldrich Co.). The conductive porous sheet was prepared by thorough mixing of carbon and PTFE powder, extruding the uniform mixture into a sheet and then expanding it on a silver-plated nickel mesh as a current collector. The carbon supported PtPd and PtRu electrocatalysts are synthesized by sodium borohydride reduction method $[12,13]$. The carbon supported PtPd, PtRu and PtAg are loaded over the gas diffusion layer of each cathode with $0.53,0.64$ and $0.6 \mathrm{mg} \cdot \mathrm{cm}^{-2}$ density, respectively as reaction layer.

\subsection{Cathode Performance Measurement}

The cell performance evaluation is carried out in the laboratory scale zero-gap type CA membrane set-up. The cell includes an ion-exchange membrane (Flemion ${ }^{\mathbb{B}} 892$, Asahi Glass Co.) which divides the cell into a chamber with standard coated titanium plate $\left(\mathrm{DSA}^{\circledR}-\mathrm{Cl}_{2}\right)$ as anode and another chamber with a prepared oxygen-depolarized as cathode. The prepared cathode was in close contact with the ion-exchange membrane and the electrocatalyst layer facing to the cathode chamber. In the zerogap design, which is used throughout this study, flooding 
by caustic solution is prevented, voltage and peroxide formation are reduced [4,5]. During the brine electrolysis, the anolyte is continuously fed into the jacketed heater anode chamber with a digital thermometer to monitor its temperature. Moreover, the anolyte $\mathrm{pH}$ was controlled by the feed $\mathrm{pH}$ and its circulation. The anode and cathode chamber overflows are conducted to different separators for further depleted reactant separation and recirculation. The preheated humidified oxygen at atmospheric pressure is used as cathode chamber feed. The cell current is kept constant and the corresponding cell voltages are measured. In order to measure the caustic produced, catholyte samples were collected and titrated against $1.0 \mathrm{M}$ $\mathrm{HCl}$ solution. These data are then used for calculation of the caustic current efficiency.

\section{Results and Discussions}

\subsection{Cathode Characterization}

The cathodes surfaces of bimetallic Pt-based alloy electrocatalysts are investigated using scanning electron microscope (SEM) with a XL30 Philips Co. microscope (Figure 3). The SEM cathodes surfaces of the loaded bimetallic Pt-based alloy electrocatalysts indicate totally different particles sizes and also their relatively uniform dispersion. The likely reason may be the way of painting to load electrocatalysts particles.

The oxygen-depolarized cathodes must be sufficiently hydrophobic to prevent the intrusion of catholyte into electrode pores and consequently, prevent electrode flooding. Hydrophobicity evaluation was made through water contact angle measurements and the results confirm the cathodes surfaces hydrophobicity as is shown in Figure 4. The hydrophobic surfaces have water contact angles larger than $90^{\circ}$. As is expected, the result indicate that water contact angle on the cathode surface increases as cathode PTFE/carbon composition changes from 30/70 to $35 / 65$. Generally, the cathodes that are loaded with bimetallic Pt-based alloy electrocatalysts show high electronic conductivity, sufficient hydrophobicity and mechanical strength.

\subsection{Cathode Performance}

One of the valuable responses which are directly proportional to total energy consumed by an electrolysis cell is the current efficiency. The caustic current efficiency (CCE) as cell performance was thus measured according to the procedure described in Section 2 and calculated based on the following equation [14]:

$$
\operatorname{CCE}(\%)=\frac{m(t)-m(t=0)}{(I t / n F) \times M W_{N a O H}}
$$

The five process parameters affecting the advanced chlore-alkali cells performance include current density, Brine concentration, Anolyte $\mathrm{pH}$, cell temperature and oxygen flow rate in the presence of different cathodes loaded with carbon supported PtRu, PtPd and PtAg and the same DSA-Cl $\mathrm{Cl}_{2}$ anode based on our pervious works $[10,11]$ are compared as shown in Figures 5-9.

The CCE of the cells using $\mathrm{PtRu} / \mathrm{C}, \mathrm{PtPd} / \mathrm{C}$ and $\mathrm{PtAg} / \mathrm{C}$ electrocatalysts increases with cell temperature increase as seen in Figure 5. This may be due to the fact that cell temperature has impacts on the rate of oxygen reduction and the electrolyte conductivity [15]. Besides, the $\mathrm{CCE}$ increase is more sensible in the $\mathrm{PtRu} / \mathrm{C}$ and

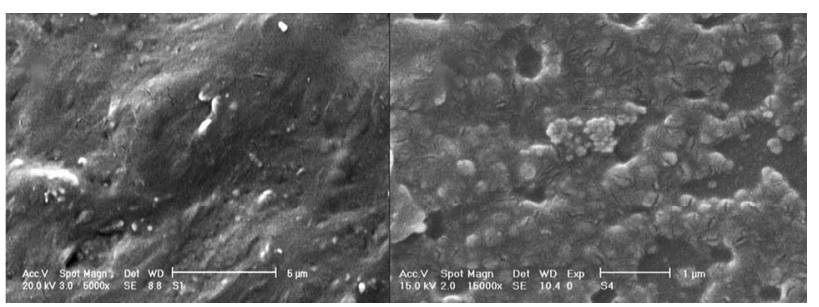

(a)

(b)

Figure 3. Scanning Electron Microscope (SEM) images of cathodes surface with; (a) PtRu, (b) PtPd, electrocatalysts.

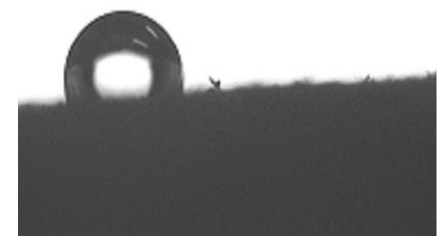

(a)

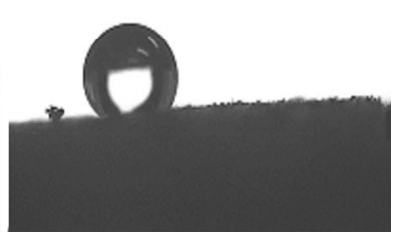

(b)
Figure 4. Contact angles $>90^{\circ}$; PTFE/carbon cathode composition of: (a) 30/70 and (b) 35/65.

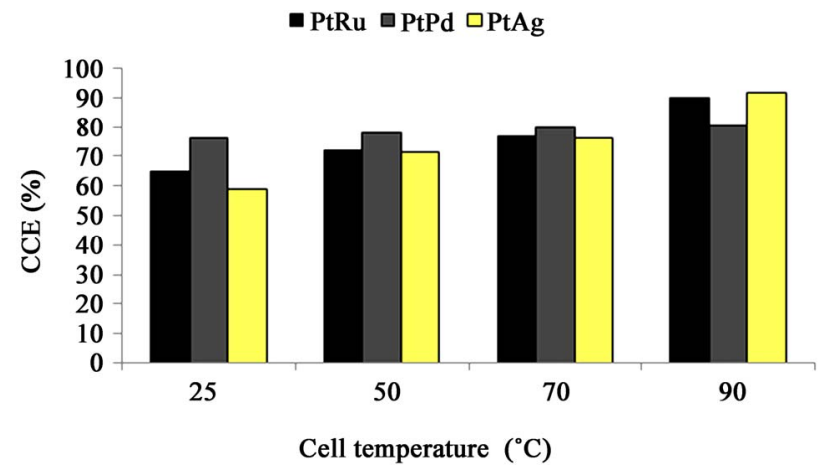

Figure 5. Cell performance (CCE (\%)) vs. cell temperature, different PtRu/C, PtPd/C and PtAg/C electrocatalysts oxygen-depolarized cathodes and the same $\mathrm{DSA}-\mathrm{Cl}_{2}$ anode. (Brine concentration: 230 g/l, Anolyte pH: 2.5, Oxygen flow rate: $500 \mathrm{~cm}^{3} / \mathrm{min}$, Current density: $2 \mathrm{kA} / \mathrm{m}^{2}$, Anolyte flow rate: $350 \mathrm{~cm}^{3} / \mathrm{min}$.) 
$\mathrm{PtAg} / \mathrm{C}$ electrocatalyst cathodes than the cathode with $\mathrm{PtPd} / \mathrm{C}$ electrocatalyst layer with temperature increase. The cell with $\mathrm{PtPd} / \mathrm{C}$ cathode shows a minimum CCE at a cell temperature of $90^{\circ} \mathrm{C}$. This result indicates that the cell temperature effect on cell performance using $\mathrm{PtPd} / \mathrm{C}$ electrocatalyst cathode is less than other cells.

The cells $\mathrm{CCE}(\mathrm{PtRu} / \mathrm{C}, \mathrm{PtPd} / \mathrm{C}$ and $\mathrm{PtAg} / \mathrm{C}$ electrocatalysts) are plotted against anolyte $\mathrm{pH}$ in Figure 6. The results show that the CCE increases as the brine acidity decrease (i.e. increasing anolyte $\mathrm{pH}$ ). It is probable that the increase of brine $\mathrm{PH}$ increases $\mathrm{H}_{3} \mathrm{O}^{+}$charge pass through membrane and therefore lowering the membrane resistance and caustic concentration [16]. The result is the cells CCE decrease.

The oxygen flow rate effect on CCE is likely related to ease of caustic removal from the cathode pores at high oxygen flow rate. The corresponding results of the cells using $\mathrm{PtRu} / \mathrm{C}, \mathrm{PtPd} / \mathrm{C}$ and $\mathrm{PtAg} / \mathrm{C}$ electrocatalysts are depicted in Figure 7 and the increase of oxygen flow rate enhances the $\mathrm{CCE}$. The results show that the $\mathrm{PtPd} / \mathrm{C}$ cathode $\mathrm{CCE}$ at low oxygen flow rate is higher than the other cathodes (PtRu/C and PtAg/C) in chlor-alkali cell.

The CCE increases with brine concentration as a consequence of lower caustic crossover [17] for all cathodes (i.e. $\mathrm{PtRu} / \mathrm{C}, \mathrm{PtPd} / \mathrm{C}$ and $\mathrm{PtAg} / \mathrm{C}$ ) as Figure 8 shows. The cell with $\mathrm{PtRu} / \mathrm{C}$ cathode shows higher $\mathrm{CCE}$ at brine concentration of $300 \mathrm{~g} / \mathrm{l}$. Figure 9 shows the CCE decrease as the current density increases from 1 to $4 \mathrm{kA} / \mathrm{m}^{2}$ for all mentioned (PtRu/C, PtPd/C and PtAg/C) cathodes. This is the result of the different 2- or 4-electron oxygen reduction reactions kinetics $[17,18]$. At the same current density, the $\mathrm{PtPd} / \mathrm{C}$ electrocatalyst cell shows higher $\mathrm{CCE}$ compared to the other cathode cells.

The oxygen reduction reaction is a complex process involving four coupled proton and electron transfer steps. Several of the elementary steps involve intermediate reactions leading to a wide choice of reaction pathways.

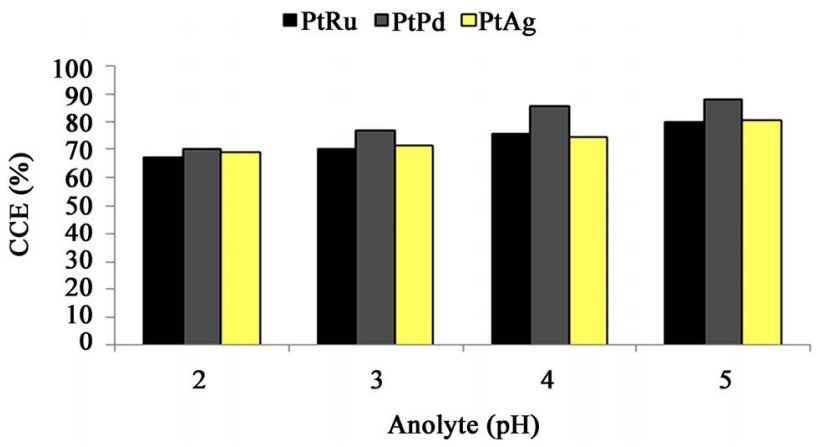

Figure 6. Cell performance (CCE\%) vs. anolyte $\mathrm{pH}-\mathrm{oxy}-$ gen-depolarized cathodes fabricated with PtRu/C, PtPd/C and PtAg/C electrocatalysts and the same $\mathrm{DSA}-\mathrm{Cl}_{2}$ anode. (Brine concentration: $210 \mathrm{~g} / \mathrm{l}$, Temperature: $75^{\circ} \mathrm{C}$, Oxygen flow rate: $500 \mathrm{~cm}^{3} / \mathrm{min}$, Current density: $2 \mathrm{kA} / \mathrm{m}^{2}$, Anolyte flow rate: $350 \mathrm{~cm}^{3} / \mathrm{min}$.)

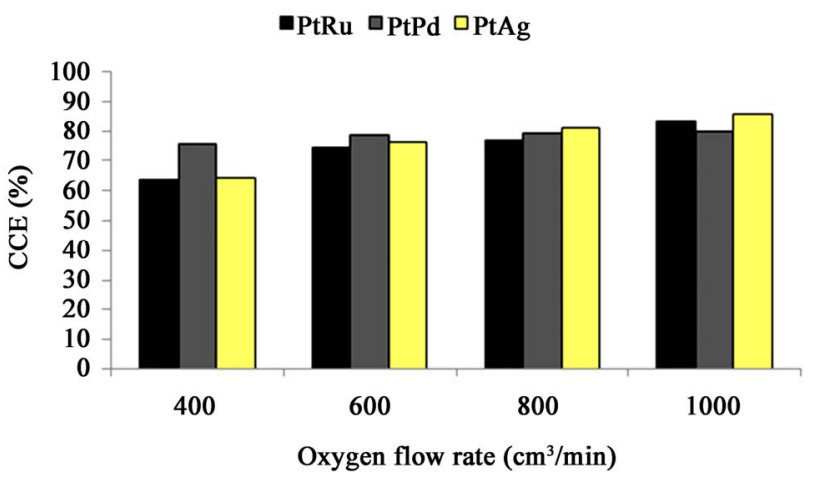

Figure 7. Cell performance (CCE \%) vs. oxygen flow rateoxygen-depolarized cathodes fabricated with PtRu/C, PtPd/C and $\mathrm{PtAg} / \mathrm{C}$ electrocatalysts and the same $\mathrm{DSA}-\mathrm{Cl}_{2}$ anode. (Current density: $2 \mathrm{kA} / \mathrm{m}^{2}$, Temperature: $80^{\circ} \mathrm{C}$, Oxygen flow rate: $700 \mathrm{~cm}^{3} / \mathrm{min}$, Anolyte $\mathrm{pH}: 2.5$, Anolyte flow rate: $350 \mathrm{~cm}^{3} / \mathrm{min}$.)

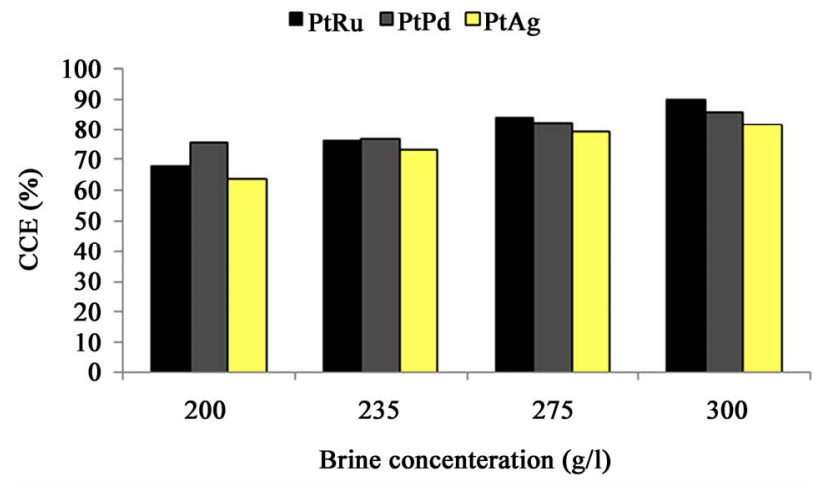

Figure 8. Cell performance (CCE (\%)) vs. brine concentration-oxygen-depolarized cathodes fabricated with $\mathrm{PtRu} / \mathrm{C}$, $\mathrm{PtPd} / \mathrm{C}$ and PtAg/C electrocatalysts and the same $\mathrm{DSA}-\mathrm{Cl}_{2}$ anode. (Brine concentration: $250 \mathrm{~g} / \mathrm{l}$, Temperature: $70^{\circ} \mathrm{C}$, Current density: $2 \mathrm{kA} / \mathrm{m}^{2}$, Anolyte $\mathrm{pH}: 2.5$, Anolyte flow rate: $350 \mathrm{~cm}^{3} / \mathrm{min}$.)

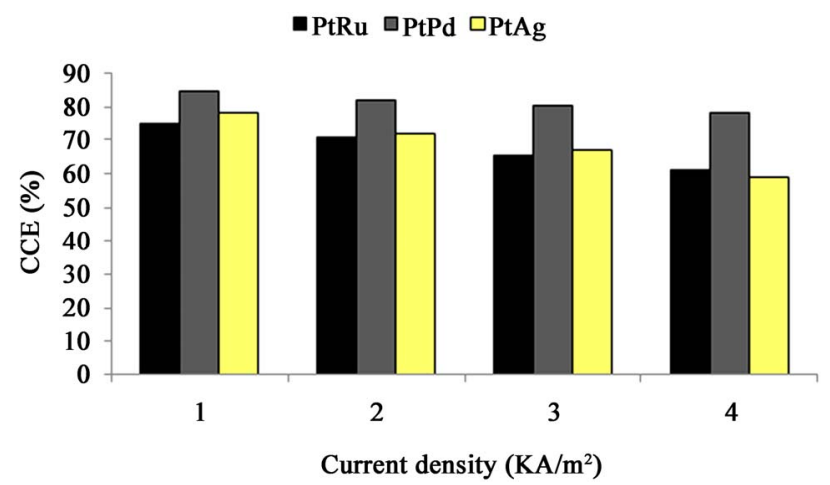

Figure 9. Cell performance (CCE (\%)) vs. current density-oxygen-depolarized cathodes fabricated with PtRu/C, $\mathrm{PtPd} / \mathrm{C}$ and PtAg/C electrocatalysts and the same $\mathrm{DSA}-\mathrm{Cl}_{2}$ anode. (Brine concentration: $270 \mathrm{~g} / \mathrm{l}$, Temperature: $80^{\circ} \mathrm{C}$, Oxygen flow rate: $800 \mathrm{~cm}^{3} / \mathrm{min}$, Anolyte $\mathrm{pH}$ : 3, Anolyte flow rate: $350 \mathrm{~cm}^{3} / \mathrm{min}$.) 
The exact sequence of the reactions is still not known and all reaction steps, intermediate reactions and their kinetic parameters must be identified, which is clearly challenging. Relatively stable $\mathrm{HO}^{2-}$ ion formation may stop the oxygen reduction reaction in alkaline electrolytes that easily converts to dioxide. Although there is no consensus on the exact reaction sequence, two overall pathways direct 4-electron and peroxide pathway may take place in alkaline media [19]:

$$
\begin{aligned}
& \mathrm{O}_{2}+2 \mathrm{H}_{2} \mathrm{O}+4 \mathrm{e} \rightarrow 4 \mathrm{OH}^{-} \\
& \mathrm{O}_{2}+2 \mathrm{H}_{2} \mathrm{O}+2 \mathrm{e} \rightarrow \mathrm{OH}^{-}+\mathrm{HO}_{2}^{-} \\
& \mathrm{HO}_{2}^{-}+2 \mathrm{H}_{2} \mathrm{O}+2 \mathrm{e} \rightarrow 3 \mathrm{OH}^{-}
\end{aligned}
$$

The produced peroxide may also undergo catalytic decomposition as follows:

$$
2 \mathrm{HO}_{2}^{-} \rightarrow 2 \mathrm{OH}^{-}+\mathrm{O}_{2}
$$

Platinum is the most commonly used and active catalyst for oxygen reduction reaction and all of the platinum-group metals reduce in alkaline media according to the direct 4-electron process [20,21]. Pt-based alloys have been studied and generally exhibit higher activity and stability than pure Pt. The enhanced Pt-alloy electrocatalytic activity is explained by a number of phenomena, such as: 1) Pt-Pt bond length reduction, favoring the oxygen adsorption, 2) Pt 5d orbital electron density 3 ) the surface oxide layers [22].

The enhanced oxygen reduction reaction activity on $\mathrm{Pt} / \mathrm{Pd}$ as an effect of stronger oxygen adsorption on $\mathrm{Pt}$ surfaces has been cited by others as inhibiting factor during $\mathrm{O}_{2}$ reduction in alkaline media. Examination of the Pt monolayers on the various metal substrates (such as $\mathrm{Ag}, \mathrm{Pd}$ and $\mathrm{Ru}$ ) revealed that $\mathrm{Pt}(\mathrm{III})$ was already close to optimal, in terms of d-band center (in determining oxygen reduction reaction activity). $\mathrm{Pd} / \mathrm{Pt}$ is the only system that shows slightly higher activity [23].

\section{Conclusions}

Commercial progression difficulties of the chlor-alkali membrane cells using oxygen-depolarized cathodes are investigated. The oxygen-depolarized cathode's main drawback is loss performance under harsh conditions in chlor-alkali cell. Using bimetallic PtRu carbon-supported electrocatalysts in oxygen-depolarized cathode chloralkali cell has shown an appropriate way to improve or enhance the performance of chlor-alkali membrane cells. The employment of bimetallic Pt-based alloy electrocatalysts including PtRu, PtPd and PtAg carbon-supported in oxygen-depolarized chlor-alkali cells is compared with each others. There are quite similarity between the effects of various factors on the CCE in a zero- gap oxygen-depolarized chlor-alkali cell employing carbon-supported PtPd, PtRu and PtAg electrocatalysts. It seems that the PtPd/C electrocatalyst cathode has relatively higher performance than the other cathodes with $\mathrm{PtAg} / \mathrm{C}$ and $\mathrm{PtRu} / \mathrm{C}$ electrocatalysts in zero-gap chloralkali cells.

\section{References}

[1] N. Furuya and H. Aikawa, "Comparative Study of Oxygen Cathode Loaded with $\mathrm{Ag}$ and $\mathrm{Pt}$ Catalysts in Chlor-Alkali Membrane Cells," Electrochimica Acta, Vol. 45, No. 25-26, 2000, pp. 4251-4256. doi:10.1016/S0013-4686(00)00557-0

[2] T. Morimoto, K. Suzuki, T. Matsubara and N. Yoshida, "Oxygen Reduction Electrode in Brine Electrolysis," Electrochimica Acta, Vol. 45, No. 25, 2000, pp. 4257-4262. doi:10.1016/S0013-4686(00)00558-2

[3] Y. Kiros, M. Pirjamali and M. Bursell, "Oxygen Reduction Electrolysis in Chlor-alkali Cells," Electrochimica Acta, Vol. 51, No. 16, 2006, pp. 3346-3350. doi:10.1016/j.electacta.2005.10.024

[4] J. Chlistunoff, "Advanced Chlor-Alkali Technology," Final Technical Report, Los Alamos National Laboratory, New Mexico, 2004.

[5] L. Lipp, S. Gottesfield and J. Chlistunoff, "Peroxide Formation in a Zero-Gap Chlor-Alkali Cell with Oxygen-Depolarized Cathode," Journal of Applied Electrochemistry, Vol. 35, No. 10, 2005, pp. 1015-1021. doi:10.1007/s10800-005-7340-7

[6] A. A. Lindley, "An Economic and Environmental Analysis of the Chlor-Alkali Production Process," Final Report, European Commission (DG III C-4, Chemicals, Plastics, Rubber), 30 June 1997.

[7] M. Sugiyama, K. Saiki, A. Sakata, H. Aikawa and N. Furuya, "Accelerated Degradation Testing of Gas Diffusion Electrodes for the Chlor-Alkali Process," Journal of Applied Electrochemistry, Vol. 33, No. 10, 2003, pp. 929932. doi:10.1023/A:1025899204203

[8] F. Federico, G. N. Martelli and D. Pinter, "Gas-Diffusion Electrodes for Chlorine-Related (Production) Technologies," In: J. M. House, Ed., Modern Chlor-Alkali Technology, Proceedings of the 2000 London International Chlorine Symposium Organized by SCI's Electrochemical Technology Group, London, 31 May-2 June 2000, Blackwell Science, Malden, 2000, 2001, pp. 114-127.

[9] R. Beckmann and B. Lüke, "Know-How and Technology-Improving the Return on Investment for Conversions, Expansions and New Chlorine Plants," In: J. M. House, Ed., Modern Chlor-Alkali Technology, Proceedings of the 2000 London International Chlorine Symposium Organized by SCI's Electrochemical Technology Group, London, 31 May-2 June, Blackwell Science, Malden, 2000, pp. 114-127.

[10] M. Habibi, E. Joudaki, F. Mohseni and A. R. Heidari, "Oxygen Reduction on Oxygen Diffusion Cathode with Pt/Ag Electrocatalyst Layer," International Journal of 
Applied Engineering Research (IJAER), Vol. 5, No. 4, 2010, pp. 633-639.

[11] E. Joudaki, F. Farzami,V. Mahdavi and S. J. Hashemi, "Performance Evaluation of Oxygen-Depolarized Cathode with Carbon Supported PtPd Electrocatalyst Layer In Advanced Chlor-Alkali Cell," Chemical Engineering \& Technology, Vol. 33, No. 9, 2010, pp. 1525-1530, doi:10.1002/ceat.201000053

[12] J. H. Choi, K. W. Park, B. K. Kwon and Y. E. Sung, "Methanol Oxidation on $\mathrm{Pt} / \mathrm{Ru}, \mathrm{Pt} / \mathrm{Ni}$ and $\mathrm{Pt} / \mathrm{Ru} / \mathrm{Ni}$ Anode Electrocatalysts at Different Temperatures for DMFCs," Journal of the Electrochemical Society, Vol. 150, No. 7, 2003, pp. A973-A978. doi:10.1149/1.1581011

[13] Y. H. Cho, B. Choi, Y. H. Cho, H. S. Park and Y. E. Sung, "Pd-Based PtPd (19:1)/C Electrocatalysts as an Electrode in PEM Fuel Cell," Electrochemistry Communications, Vol. 9, No. 3, 2007, pp. 378-381. doi:10.1016/j.elecom.2006.10.007

[14] R. R. Chandrand and D. T. Chin, "Reactor Analysis of Chlor-Alkali Membrane Cell," Journal of Applied Electrochemistry Acta, Vol. 31, No. 1, 1986, pp. 39-50.

[15] A. A. Jalali, M.Sc. Thesis, Iran University of Science and Technology, 2005.

[16] J. L. Fernández, M. R. G. De Chialvo and A. C. Chialvo, "Preparation and Electrochemical Characterization of Ti/RuxMn1- $\mathrm{xO}_{2}$ Electrodes," Journal of Applied Electrochemistry, Vol. 32, No. 5, 2002, pp. 513-520. doi:10.1023/A:1016592404691

[17] J. T. Keating and H. M. B. Gerner, "High Current Density Operation-The Behavior of Ion Exchange Membranes in Chlor-Alkali Electrolyzers," In: S. Sealey, Ed.,
Modern Chlor-Alkali Technology, Proceedings of the 1997 London International Chlorine Symposium Organized by SCI Electrochemical Technology Group, Vol. 7, London, 4-6 June 1997, pp. 135-144.

[18] T. Mirzazadeh, F. Mohammadi, M. Soltanieh and E. Joudaki, "Optimization of Caustic Current Efficiency in a Zero-Gap Advanced Chlor-Alkali Cell with Application of Genetic Algorithm Assisted by Artificial Neural Network", Chemical Engineering Journal, Vol. 140, No. 1-3, 2008, pp. 157-164. doi:10.1016/j.cej.2007.09.028

[19] E. Yeager, "Electrocatalysts for $\mathrm{O}_{2}$ Reduction," Electrochimica Acta, Vol. 29, No. 1, 1984, pp. 1527-1537. doi:10.1016/0013-4686(84)85006-9

[20] D. B. Sepa, M. V. Vojnovic, M. Stojanovic and A. Damjanvic, "Different Views Regarding the Kinetics and Mechanisms of Oxygen Reduction at Pt and Pd Electrodes," Electrochimica Acta, Vol. 32, No. 1, 1987, pp. 129-134. doi:10.1016/0013-4686(87)87021-4

[21] D. B. Sepa, M. V. Vojnovic, M. Stojanovic and A. Damjanvic, "Kinetics of Oxygen Reduction at Iridium Electrodes in Aqueous Solutions," Journal of Electroanalytical Chemistry, Vol. 218, 1987, pp. 265-272. doi:10.1016/0022-0728(87)87021-3

[22] F. Bidault, D. J. L. Brett, P. H. Middleton and N. P. Brandon, "Review of Gas Diffusion Cathodes for Alkaline Fuel Cells," Journal of Power Sources, Vol. 187, No. 1, 2008, pp. 39-48. doi:10.1016/j.jpowsour.2008.10.106

[23] J. S. Spendelow and A, Wieckowski, "Electrocatalysis of Oxygen Reduction and Small Alcohol Oxidation in Alkaline Media," Physical Chemistry Chemical Physics, Vol. 9, No. 21, 2007, pp. 2654-2675. doi:10.1039/b703315j 